Social factors are strongly at work in the process of educational selection. The report under review, like that of the Central Advisory Council for Education in England ("Early Leaving", H.M. Stationery Office ; 1954), although in a technically more refined manner, shows a relationship in the selective secondary school between the father's occupational class and a child's chances of completing the course and proceeding to advanced work which is practically independent of intelligence quotient $(I Q)$. Thus, in the Scottish sample, for able boys with an $I Q$ greater than 120 coming from working-class families (namely, those whose fathers are manual workers) the chances of completing the course are about 2 in 5 ; but for similarly able boys from other (that is to say, nonmanual) families, the chances are about 2 in 3 . For those with an IQ less than 120 there is the same difference in chances according to social background; for working-class boys at this level of ability they are about 1 in 5, but for others 1 in 2. However, the Scottish report explores the implications of this striking finding much less thoroughly and imaginatively than the English report. Related findings, such as that early leavers tend to be deficient in personal qualities such as industry, or had very difficult home circumstances, or did not find the course interesting or useful for the career they had in mind, or were known not to be succeeding in the course for other known or unknown reasons, are accepted at their face-value as psychological irreducibles. The English report, on the other hand, examines the possibility that those factors are systematically related to sociological variables such as father's occupation, size and sex of the school, or the social and economic character of the neighbourhood in which it is situated. Clearly these are the lines, sociological rather than psychological, on which further work on the problems of educational selection and performance must proceed. JEAN FLOUD

\section{CRITIQUE OF WITTGENSTEIN'S PHILOSOPHY}

The Later Philosophy of Wittgenstein

A Short Introduction, with an Epilogue on John Wisdom. By Dr. David Pole. Pp. vi +132. (London: The Athlone Press, University of London, 1958. Distributed by Constable and Co., Ltd.) 15s. net.

$\mathrm{N}$ this book, small in size but weighty in learning, 1 Dr. D. Pole sets out to be an interpreter and, in part, critic of Wittgenstein's later thought as expressed in his posthumous writings. Appropriately enough, a chapter is included on the work of Prof. Wisdom, whose method is characteristically British, though he has done much to graft it on (and this is in itself no mean achievement) to the Germanic, and even Hegelian strain running through Wittgenstein.

These essays begin with a discussion of the linguistic approach to philosophy, followed by some detailed observations upon logic and normative language, together with the place of inner experience. The main theme is rounded off by a consideration of the difficulties in Wittgenstein's philosophy. In all this, one cannot be blind to the immense change which came over Wittgenstein since he first startled the learned world with the "Tractatus" in 1922.

A favourite illustration is that of a machine running idle, or of a wheel spinning freely without engaging with the rest of the machinery. Such a mental situation derives from forgetting that language is something which we inherit, whereas a calculus is a deliberate construct. Noteworthy, too, is the view that for Wittgenstein a mathematician is more an inventor than a discoverer.

Yet Wittgenstein, himself no professional mathematician, helped that discipline substantially in several ways, not least by the realization that "in working with shapes, we create our concepts".

Perhaps it is hereabouts that Wittgenstein makes an incidental contribution of importance to psychology in throwing up, as it were, the nature of boundaries as perceived in geometric figures. This is common ground for Gestalt-theorie, behaviourism, and even for parts of isomorphism. Some of these may be out of fashion but they are part of man's heritage, and Dr. Pole has done well to include hints of them in his valuable study.

F. I. G. RAwLINS

\section{THE CLERK IN INDUSTRY}

\section{The Blackcoated Worker}

A Study in Class Consciousness. By David Lockwood. (Studies in Society.) Pp. 224. (London: George Allen and Unwin, Ltd., 1958.) 21 s. net.

THE position of the clerk in industry and commerce has changed considerably during the past forty years. Before the First World War the clerk commanded authority and respect vis-a-vis the manual worker. Because of his closeness to the employer he was paid more, was treated as a person of considerable status both because of his knowledge of the company's secrets and because of his literacy, and often succeeded to posts of management responsibility because of his experience in administration. Now, as David Lockwood shows in a scholarly, wellplanned and carefully written investigation, the clerk's position is generally very different.

In the days of the counting-house, clerks were nearly all male and were recruited from middle-class families, frequently from the homes of clerks themselves. To-day, much of the work in a mechanized office is done by females, many of whorn-as well as their male counterparts - are recruited from the lower. social strata. Up to 1914 the ordinary adult clerk earned roughly the same as a skilled manual worker. In 1958 even the aristocracy of blackcoated labourthe banking and insurance elerks-no longer enjoy an economic status clearly distinct from the wageearning classes; the mass of clerks are roughly on the same income-level as the average manual worker. The clerk's position is also changing relative to that of the manual worker with regard both to job security and 'fringe' benefits.

These are some of the generalizations which emerge from factual information so painstakingly gathered and sifted by the author. They reinforce the experi. ences of all who are concerned with the place of the elerk in industry and commerce and should illuminate the implication of modern trends. Reduced pay differentials, greater job insecurity and the difficulty of finding other jobs when declared redundant, as well as lessened chances of promotion with the introduction of management trainees, are some of the factors combining to make the clerk's position more unstable. As a consequence, many firms are already finding it difficult to recruit sufficient clerks of the right quality. Lockwood's book should be read by all employers who are faced with this problem and are prepared to tackle it before it becomes too unwieldy. 